\title{
Contesting a Place in the Sun: On Ideologies in Foreign Markets and Liabilities of Origin
}

\author{
Ans Kolk ${ }^{1} \cdot$ Louise Curran ${ }^{2}$
}

Received: 18 December 2014/ Accepted: 4 October 2015/Published online: 13 October 2015

(c) The Author(s) 2015. This article is published with open access at Springerlink.com

\begin{abstract}
This paper explores the role of ideology in attempts to influence public policy and in business representation in the EU-China solar panel anti-dumping dispute. It exposes the dynamics of international activity by emergingeconomy multinationals, in this case from China, and their interactions in a developed-country context (the EU). Theoretically, the study also sheds light on the recent notion of 'liability of origin', in addition to the traditional concept of 'liability of foreignness' explored in international business research, in relation to firms' market and political strategies and their institutional embeddedness in home and host countries. Through a qualitative analysis of primary and secondary materials and interview data with key protagonists, we provide a detailed evolution of the case, the key actors involved and their positions, arguments and strategies. This illustrates the complexities involved in the interaction between markets and ideologies in the midst of debates regarding different forms of subsidy regimes for renewable energy, free trade versus protectionist tendencies by governments, and the economic and sustainability objectives of firms and societies. The case shows how relative newcomers to the EU market responded to overcome a direct threat to their business and became, with support from their home government, active participants in the public debate through interactions with local commercial partners and non-governmental organisations. Firms adopted relatively sophisticated strategies to
\end{abstract}

Ans Kolk

akolk@uva.nl;

http://www.anskolk.nl

1 University of Amsterdam Business School, Plantage Muidergracht 12, 1018 TV Amsterdam, The Netherlands

2 Toulouse Business School, Université de Toulouse, Toulouse, France reduce their liabilities vis-à-vis host-country institutions and local stakeholders, including collective action, to increase their legitimacy and reputation, and counter ideologically based attacks. We also discuss implications and limitations.

Keywords Sustainability - Multinationals · Liability of foreignness - Liability of origin . China $\cdot$ EU $\cdot$ Solar panels $\cdot$ Trade policy

\begin{tabular}{|c|c|}
\hline \multicolumn{2}{|c|}{ Abbreviations } \\
\hline AFASE & $\begin{array}{l}\text { Alliance for Affordable Solar Energy- } \\
\text { grouping of companies against duties }\end{array}$ \\
\hline EPIA & $\begin{array}{l}\text { European Photovoltaic Industry } \\
\text { Association—official EU level trade } \\
\text { association }\end{array}$ \\
\hline EMNE & Emerging-market multinational enterprise \\
\hline EU ProSun & $\begin{array}{l}\text { Grouping of companies who supported } \\
\text { duties }\end{array}$ \\
\hline FDI & Foreign Direct Investment \\
\hline LOF & Liability of foreignness \\
\hline LOR & Liability of origin \\
\hline MNE & Multinational enterprise \\
\hline NGO & Non-governmental organisation \\
\hline NME & Non-market economy \\
\hline SETI & $\begin{array}{l}\text { Sustainable Energy Trade Initiative-an } \\
\text { alliance of NGOs, companies and } \\
\text { governments supportive of efforts to } \\
\text { liberalise trade in environmental goods }\end{array}$ \\
\hline
\end{tabular}

\section{Introduction}

In the recent years, there has been considerable controversy regarding imports of Chinese solar panels into the US and, most recently, into Europe. While some of the aspects 
surrounding the alleged dumping of these low-cost panels are rather technical and in the realm of trade law and industrial engineering (Carbaugh and St. Brown 2012; Curran 2015; Erixon 2014; Van de Graaf 2013), the matter also raises broader questions concerning the mobilisation of ideologies in markets and international business. Considered in terms of the patterns or framework of ideas, as ideologies are conceptualised in the call for papers for this special issue, the dispute around Chinese solar panels is somewhat puzzling in that different perspectives have been taken on what can also be framed as an ethical issue. In the context of global concerns about climate change, renewable energies, including solar, have been embraced for their potential contribution to a lower-carbon economy. While concerted action and the implementation of international agreements have been difficult, the preservation of the planet and the consequent need to reduce greenhouse gas emissions might be considered an international moral norm for business (Bowie 1997; Tully 2005). Perhaps it has even become a 'market morality' (Bowie and Vaaler 1999), given corporate recognition of the sustainability principle as both a requirement for international business and a potential source of competitive advantage (Kolk and Pinkse 2008).

With affordability for broad sections of the population as an additional consideration, government support has become quite common in this sector by way of subsidies and incentives for producers and/or buyers, sometimes as part of wider stimulus plans (Haley and Schuler 2011). Examples include the green bailout efforts following the financial crisis in several countries and longer-standing feed-in tariffs in Germany and several other EU countries (for an overview, see Lewis 2014; cf. EPIA 2012; Pinkse and Kolk 2012). This latter type of stimulation has resulted in a much quicker adoption and installation of solar panels in these countries than would otherwise have been the case (Quitzow 2015). Against this background, the strong objections to the widespread availability of relatively lowcost panels from China on foreign markets seem somewhat surprising. That these were developed and subsequently offered cheaply abroad by Chinese companies thanks to support from their home government, under-cutting the European or the US producers, apparently superseded environmental and affordability considerations (Carbaugh and St. Brown 2012; Dunford et al. 2013; Lewis 2014). Although various concrete economic arguments were marshalled by proponents of anti-dumping measures and other forms of trade defence, including references to presumed job losses (ProSun 2013a), often ideological factors also seemed to be at play.

This paper analyses the role of ideology in attempts to influence public policy and in business representation in the EU solar panel anti-dumping dispute, using a case- study approach. In addition to providing more insight into the interaction between markets and ideologies, it examines the dynamics of international activity by emergingmarket multinational companies, in this case from China, in developed-country markets (the EU). The analysis contributes to international business theories, shedding light on the recent notion of 'liability of origin' that has emerged to complement the more traditional 'liability of foreignness' faced by multinationals operating abroad (Pinkse and Kolk 2012; Ramachandran and Pant 2010; Stevens and Shenkar 2012). While dimensions of the liability of origin have been identified conceptually, empirical exploration has hitherto been lacking, as discussed in the next section. The overview of the most relevant literature is followed by an explanation of the research approach and background of the case. We subsequently present and discuss the findings. The final section concludes and considers implications and limitations.

\section{Complexities of Doing Business in Foreign Markets}

The difficulties of accessing and/or operating in foreign markets have long concerned scholars in international business and management, reflecting the practical experiences of firms over the years. Whether labelled 'the cost of doing business abroad' or, subsequently, the 'liability of foreignness' (LOF) (e.g. Zaheer 1995), what the different concepts share is the focus on the problems faced by multinational enterprises (MNEs) in their activities outside their home country (Sethi and Judge 2009). As aptly summarised by Denk et al. (2012), this body of literature has yielded useful insights concerning, inter alia, the impact of LOF on firms and their performance, and the categorisation of the costs of doing business abroad into different categories (e.g. Eden and Miller 2004; Zaheer 2002). Much work has focused on identifying and especially quantifying how LOF impacts firms, often using large datasets (Mezias 2002; Miller and Eden 2006; Zaheer 1995; Zaheer and Mosakowski 1997). In terms of categorisation, Eden and Miller (2004) differentiated between LOF linked to unfamiliarity, discrimination and relational hazards. The case we explore here is very much a discriminatory hazard, i.e. one which emerges from differential government treatment and/or customer ethnocentricity, aspects typically difficult to assess through survey or database research.

In the existing literature, certain aspects have remained underexplored. First, LOF research has thus far concentrated on Foreign Direct Investment (FDI) by developedcountry MNEs. Despite their growing importance, there has been little work on emerging-economy MNEs 
(abbreviated as EMNEs or sometimes EE MNEs), which often still focus on the so-called market-seeking investments. As this type of FDI activity is directly linked to trade (and thus to possible discrimination against foreign products) by newcomers on established markets, it is a subset that seems particularly vulnerable to LOF (Guar et al. 2011). Second, studies have paid only limited attention to approaches adopted by firms to mitigate their LOF, especially in relation to difficulties with foreign institutional contexts. This calls for a more explicit consideration of the difference in firms' home-country settings, as captured by the recently introduced notion of 'liability of origin' (LOR). LOR relates to discrimination against firms "by host country consumers and governments because of where they are from (i.e., their specific country of origin)", as opposed to LOF's focus on "where they are not from" (Ramachandran and Pant 2010, p. 243; emphases in original).

In a conceptual piece, Ramachandran and Pant (2010) note that LOR can best be understood by studying EMNEs entering developed-country markets. Building on earlier findings, particularly from international marketing, on consumer animosity and negative product-country images directed against a specific country, they formulate the expectation that "a far more significant role in the LOR of EE MNEs in developed-country markets would be played by negative perceptions, stereotypes, or beliefs regarding product or service quality associated with their country of origin" (Ramachandran and Pant 2010, p. 244). They also refer to the ideological and strategic dimensions of (foreign) governments' discrimination of an MNE from a particular country. This may stem from "friction caused by the attributes of its home country institutions" (Stevens and Shenkar 2012, p. 133) including the economic policies or the political stance of its government (Pinkse and Kolk 2012).

In recent years, several authors have underlined that EMNEs are specifically confronted with these complexities in their expansion into developed-country markets in view of what have been called institutional or 'stakeholder-mandated' differences (e.g. Cuervo-Cazurra and Genc 2008; Kolk 2010a; McGuire et al. 2012; Verbeke 2009). As emerging economies are characterised by 'underdeveloped institutions' (Cuervo-Cazurra and Genc 2008), or a combination of less active non-governmental organisations (NGOs) and lower or largely absent societal pressures and concomitant strict(er) CSR requirements (Kolk 2010a), EMNEs have more limited experience of addressing such concerns. The distance between home and host settings has been particularly pronounced in the case of China. Chinese firms consequently face high institutional costs when operating in Western contexts, including those related to negative stereotyping about Chinese products and company governance (Eden and Miller 2009). Often 'regular' disadvantages related to trade and exports that compete with (domestic) developed-country producers on their home market have been exacerbated by political, economic and CSR/sustainability considerations (Pinkse and Kolk 2012). This has gone beyond the "ethics away from home" tensions (as Donaldson 1996, put it) faced by MNEs in general, and discussed in the international business literature (e.g. Bowie 1997; Bowie and Vaaler 1999; Kolk 2015).

The EU-China solar panel dispute that we explore in this paper provides a clear example of the complexities involved in foreign markets and the role of ideologies, particularly those related to country of origin. The dispute resides within controversies surrounding climate change policy, domestic subsidy regimes for production and/or consumption of renewables, and extends to other (non-CSR) trading topics, including local-content clauses, institutional embeddedness and firms' market and political strategies (Haley and Schuler 2011; Pinkse and Kolk 2012). While MNE responses to LOF have received some attention, most studies have explored contexts of 'deep presence' resulting from investments in local production or service provision. Examples of such firm strategies include adjusting human resource policies to balance expat and local management, providing more independence to subsidiaries in certain areas and, most relevant for EMNEs, reducing unfamiliarity through learning and exchange, adapting to local circumstances through community contributions and seeking to become an 'insider' (Daamen et al. 2007; Eden and Miller 2009; Klossek et al. 2012; Mezias 2002). While the solar case involves a primarily trade-related, more 'shallow' presence, MNE responses are expected to at least partly resonate with those found in the literature.

The question of how to overcome the additional liability related to the country of origin has mainly been explored conceptually, both in general (Moeller et al. 2013) and specifically for EMNEs (Ramachandran and Pant 2010). In addition to actions at the subsidiary level, crucial for addressing LOF, LOR requires initiatives at the corporate level and by government agencies from the firm's home country, preferably simultaneously (McGuire et al. 2012), to help diminish adverse institutional attributions. Furthermore, to increase legitimacy in host countries, Ramachandran and Pant (2010) point to the possible role of institutional entrepreneurship in mobilising sufficient resources and other types of support to change perceptions. This can include collective action via industry associations that target governments and other key stakeholders as well as spreading best practices amongst members (Ramachandran and Pant 2010). Building good relationships in the host country at different levels, both individually and collectively, may promote the organisational identity of the firm and improve its reputation and corporate image. While our exploratory study is not intended to address all of these 
dimensions, it will expose some of the complexities, as explained in the research approach section.

\section{The Role of Ideology}

Ideology has been analysed in several different streams of social science but it nevertheless remains a "nebulous and slippery concept" (Fine and Sandstrom 1993, p. 22), subject to wide variations in definition and application. The most useful of the various definitions in the literature for our purposes is that of Denzau and North $(1994$, p. 4) who define ideologies as "the shared framework of mental models that groups of individuals possess that provide both an interpretation of the environment and a prescription of how that environment should be structured". Thus, ideologies are by nature normative, as they relate not just to our understanding of how things are but also to how things ought to be. As Fine and Sandstrom (1993) highlight, ideologies thus become particularly salient in relation to solving problems in the socio-political world.

In relation to the issue of how ideology influences business at the micro-level, researchers have explored how individuals' ideological beliefs impact their choices, including key issues of business ethics (Barnett et al. 1994; Bass et al. 1999). Nevertheless, there is also clearly the potential for ideological differences to affect international business activity, as the solutions to socio-political problems will vary across countries given that 'shared mental models' (Denzau and North 1994) are culturally grounded and often location based. Research on the role of ideology in the international business context mostly entails largescale quantitative work focusing on how political ideologies (usually of the right-left typology) impact economic outcomes such as the degree of state ownership (Avsar et al. 2013) or environmental protection (Garmann 2014).

What interests us here, however, is how ideologies and the 'stories' which are integral parts of their transmission (Wines and Hamilton 2009) can be harnessed by certain groups within a society in a manner that serves their interests. We therefore explore ideology as a tool, strongly linked to rhetoric "to enhance public impression (and to justify the claims and resources) of presenters and/or adherents" (Fine and Sandstrom 1993, p. 35). As Chelli and Gendron (2013, p. 190) underline, identifying such strategies involves analysing the discourse of the actors as they seek to convince the audience of "the validity or even obviousness of some ideas". Such an analysis was undertaken by Haase and Raufflet (2012) regarding the transformation of Canadian oil sands from 'dirty' to 'ethical'. Here ideology turned out to have been clearly harnessed to present OPEC producers as "unethical, unsecure and unreliable" (Haase and Raufflet 2012, p. 479), largely on the basis of their non-democratic governance, and the need to uphold 'ethics' was successfully argued to trump environmental concerns. There are similarities with the solar case examined in this article, as will be explained below.

Given that differences in governance systems provide the potential for conflicting ideological visions, it is not surprising that China's emergence as an economic power has led to controversy. Halper (2011, p. 18) argues that China" advances diplomatic, political, and economic values antithetical to those that have informed the status quo global architecture". The same author considers the capacity of China to export its 'market-authoritarian' model a threat to Western values (Halper 2010). Shortgen (2009) identifies such rhetoric as the 'China Threat' school, firmly rooted in perceptions of ideological difference, with Scott and Wilkinson (2013) arguing that this school of thought increasingly infuses attitudes to China. The potential for these perceptions to affect Chinese business expansion has been underlined by several authors, who highlight that concerns about the role of the state and stereotypes about low quality goods and questionable labour practices have the potential to create substantial LOF, or rather LOR, for Chinese firms abroad (Eden and Miller 2009; McGuire et al. 2012). Despite these statements, however, we find no substantial analysis in the literature of the interactions between such perceived ideological differences and LOF/LOR. Given the increasing number of globally active Chinese MNEs, this question merits further consideration.

On the specific issue of Chinese MNEs involvement in the solar sector, several recent articles have helped to shed light on their role in the global solar photovoltaic (PV) industry and/or related (detailed legal) trade issues between China and the US, and less often, between China and Europe (Carbaugh and St Brown 2012; Clark 2013; Curran 2015; Haley and Schuler 2011; Lewis 2014). They have highlighted the complex international production and supply networks, the rapid growth of late entrant and low-cost producer China, and the resulting overcapacity on the global market (Dunford et al. 2013; Gallagher and Zhang 2013). However, scholars have provided a generic overview of the actors and paid only very limited attention to the (collective) activities of Chinese and domestic firms, and their interactions with governments and other stakeholders as these cases evolved. This also means that the role of ideology in attempts to influence public policy and in business representation has remained unexplored. We seek to highlight this aspect of the debate.

\section{Research Approach}

Our paper follows a qualitative, case study approach to provide a deeper understanding of the context and the actors in relation to the issues at stake. In this way, it 
responds to calls by scholars that have provided overviews of both the EMNE and LOF literatures (respectively Jormanainen and Koveshnikov 2012; Luo and Mezias 2002) for more in-depth exploration. Furthermore, on the specific issue of increasing insight into EMNEs' LOR, Ramachandran and Pant (2010, p. 257) explicitly recommend "a temporary privileging of case studies over variance studies". The import of Chinese solar panels into the EU is a very pertinent case through which to explore the complexities highlighted in the previous sections, as it encompasses a country of origin where there is clear support for production (China) and a destination (foreign context) with widespread incentives for the consumer uptake (most notably in Germany but also other European countries) (Quitzow 2015; Zhang et al. 2013).

Hence, when placed in the two-by-two matrix of Haley and Schuler (2011), which distinguished government assistance to the solar photovoltaic industry for production and/or consumption, our empirical case covers countries with diametrically opposing approaches and different ideological approaches to the role of the state. China provides consistent state support to industry, which increases the tendency of Chinese firms to produce and subsequently export excess capacity, especially to countries that promote consumption (Quitzow 2015; Zhang et al. 2013). This situation is likely to culminate in confrontation, in this case in the EU, between domestic producers and foreign exporters. We extend the work by Haley and Schuler (2011), who provided a very helpful but more generic overview of government policy and firm strategy, considering firms' non-market actions in their local, domestic context, but who also acknowledged that they had ignored other relevant dimensions. Our study includes broader interactions, within an international setting and joint action via business associations.

It is important to note that the solar case is part of a wider trend towards increased trade tensions with regard to renewables and sustainability, which has affected not just solar, but also wind and biofuels (Carbaugh and St Brown 2012; Lewis 2014). These are linked to a fundamental disconnect between international rules founded on free and fair trade, on the one hand, and active government support for low-carbon energy, which by nature tends to distort markets, on the other (Carbaugh and St Brown 2012; Lewis 2014). This dissonance has given rise to legal analysis and calls for reform of the World Trade Organisation's subsidy rules to better reflect the reality of the situation and provide more 'policy space' for governments to support industry in order to achieve renewable energy targets (Rubini 2011). In the meantime, however, judgements on what is and what is not acceptable continue to vary nationally, leading to legal conflicts where jurisprudence is complex and somewhat contradictory (Mavroidis 2013).
We examined the EU-China solar panel anti-dumping dispute in detail as it unfolded from the summer of 2012 until the establishment of the minimum price undertaking a year later, and traced it subsequently, with the latest check in December 2014. It should be noted that the case is not fully concluded as efforts continue to restrict imports and review the final agreement (ProSun 2015). A timeline of the case has been constructed to provide insight into key developments and actors. Two ad-hoc groups were set up to lobby for and against anti-dumping duties, respectively EU ProSun, which also launched the case, and AFASE, the Alliance for Affordable Solar Energy. Both organisations and their websites were monitored throughout the case, and their position papers, press releases, advice for members and copies of commissioned reports analysed. We also examined the international press, particularly the Financial Times, The Economist and European Voice, and their regular reports on the progress of the case. Given the confidential nature of $\mathrm{EU}$ anti-dumping investigations, previous research has used the press as a reliable source in comparable situations (Evenett and Vermulst 2005), and for business-government interactions more generally (e.g. Pinkse et al. 2014). Finally, and despite limitations due to the (legal) sensitivity of the case, especially for regulatory bodies, we managed to conduct skype and face-to-face interviews with several key actors over the period of the proceedings and afterwards, which enabled a proper crosscheck. $^{1}$

In addition to assessing the evolution of the case, the key actors and their positions in general, we specifically analysed all of the information collected in relation to the important dimensions identified in the literature, discussed in the previous section. First, the arguments used by proponents and opponents were examined on their merits to trace ideological and strategic components. As specified in the next section, the economic and political importance of the solar panel case means that a mix of factors has been involved, often used in an interrelated way. Arguments include job losses and employment, climate change and sustainability concerns, cost and affordability of solar, product quality and issues of government support and the related 'China threat'. Second, the solar panel case was used as a lens to view how the Chinese MNEs responded. We sought to identify their strategies and tactics, including collective action, to increase their legitimacy and reputation, and reduce their LOF, and particularly LOR, in

\footnotetext{
1 We were able to interview informants on both sides of the case, including several people that were actively involved in AFASE and ProSun, in addition to market analysts of the European Photovoltaic Industry Association and a representative of the Sustainable Energy Trade Initiative. The seven interviews were spread over 2013 and 2014 (three in January 2013, one in August 2013, one in November 2013, one in May 2014 and one in October 2014).
} 
Table 1 EU market situation according to official figures, to ProSun and to AFASE

\begin{tabular}{|c|c|c|c|}
\hline $\begin{array}{l}\text { Market } \\
\text { characteristic }\end{array}$ & Official figures & According to ProSun & According to AFASE \\
\hline Market share & $\begin{array}{l}\text { Trade figures (from the ITC Trademap } \\
\text { database) indicate that Chinese imports } \\
\text { represented } 44 \% \text { of EU imports by } \$ \\
\text { value (including internal EU trade) in } \\
2011\end{array}$ & $\begin{array}{l}\text { Claimed that Chinese companies had } \\
80 \% \text { EU market share in } 2011 \text { (ProSun } \\
\text { 2012a) }\end{array}$ & $\begin{array}{l}\text { Indicated, in a press interview, that } \\
\text { Chinese market share was } 57 \% \text {. } \\
\text { Claimed that this was mainly due to } \\
\text { lack of supply capacity in the EU } \\
\text { (Choudhury 2013) }\end{array}$ \\
\hline Price falls & $\begin{array}{l}\text { Trade figures indicate that Chinese } \$ \\
\text { prices per ton fell by } 48 \% \text { between } \\
\text { June } 2011 \text { to August } 2012 \text {. Unit prices } \\
\text { from all sources fell by } 42 \% \text {. Chinese } \\
\text { prices remained } 20 \% \text { below the } \\
\text { average import price. }\end{array}$ & $\begin{array}{l}\text { Claimed that price falls were due to } \\
\text { dumping, enabled by low cost loans, } \\
\text { export support and direct government } \\
\text { support to failing companies (ProSun } \\
\text { 2013a) }\end{array}$ & $\begin{array}{l}\text { Claimed that price falls were an } \\
\text { inevitable result of economies of scale, } \\
\text { but also related to major falls in price } \\
\text { of polysilicon. EU companies were } \\
\text { locked into long-term contracts above } \\
\text { the market price, increasing their costs, } \\
\text { and many were small (AFASE 2012a) }\end{array}$ \\
\hline Bankruptcies & $\begin{array}{l}\text { No official figures. In March 2013, the } \\
\text { specialist press reported that over a } \\
\text { dozen German solar companies had } \\
\text { gone bankrupt in the previous } \\
12 \text { months (Blau 2013) }\end{array}$ & $\begin{array}{l}\text { Provided a long list of companies that } \\
\text { went bankrupt/left the solar industry on } \\
\text { website (ProSun 2013b). When last } \\
\text { updated, in October 2013, it included } \\
\text { over } 70 \text { companies, including } \\
\text { Gehrlicher }\end{array}$ & $\begin{array}{l}\text { Claimed that EU companies had adopted } \\
\text { inappropriate strategies. Pointed out } \\
\text { that 35-40\% of Chinese companies } \\
\text { had also gone bankrupt (AFASE } \\
\text { 2013a). Claimed that Gehrlicher's } \\
\text { bankruptcy was due to AD duties } \\
\text { (AFASE 2013b), although ProSun } \\
\text { argued that dumping had caused it } \\
\text { (ProSun 2013c) }\end{array}$ \\
\hline
\end{tabular}

relation to host-country institutions and local stakeholders in the EU.

\section{Findings}

This section will first give an overview of key developments and actors in the EU-China solar case, followed by the arguments that have been used, often involving a mix of factors, and a discussion of MNE response strategies to LOF and particularly to LOR.

\section{Key Developments and Actors in the Case}

The solar panel anti-dumping case unfolded against a background of very rapid increases in Chinese production capacity and an exponential growth of solar panel exports from China, which went from practically nothing in 2003 to over $40 \%$ of the world export market in 2009. By 2010, three of the top five global PV companies were Chinese (Algieri et al. 2011). This growth, based on a combination of low costs and vertical integration, also contributed to a $50 \%$ fall in prices between 2010 and 2011. These developments inevitably put pressure on market actors and on both sides of the Atlantic (Dunford et al. 2013), but the EU was the key global market for solar panels, with $75 \%$ of the total installed capacity in 2011 (EPIA 2012). In this context of rapid growth in market share, falling prices and home-government support, trade tensions were not surprising (Haley and Haley 2013).
The exact situation on the EU market is difficult to assess with certainty from public data, as calculating market shares and prices often require proprietary information. This provided the opportunity for both sides to mobilise data that reflected their ideological points of view. Thus, the two protagonists-AFASE and ProSun-presented very different perceptions of the market situation and, especially, of the reasons for market difficulties. Table 1 provides an overview of the situation in as much as it can be gauged from public data and other sources, together with the claims of both sides. It is commonly accepted that the market share of Chinese firms was high and growing, although academic analysis indicates that this was, at least in part, due to a historical lack of capacity within the EU in the face of rising market demand (Quitzow 2015). Where the two sides differ fundamentally, as explored below, is in their conclusions on the reasons for this rapid increase in market share.

As further background for the case, Table 2 presents the timeline of the EU solar anti-dumping (AD) dispute, with US developments for information. Given the focus of this paper, and in view of existing published work mentioned above, we do not go into specific legal details but will discuss relevant aspects where needed. As the overview shows, the key events of the European case were basically concentrated in one year. Interestingly, two German companies (SolarWorld and Conergy) had apparently already tried to instigate an investigation in the EU in August 2009 (Lewis 2014). While unsuccessful, this attempt illustrated rising attention to the issue in the course of a few years. 
Following a complaint from ProSun, the AD investigation was formally launched by the European Commission in September 2012. It was acknowledged to be the most significant anti-dumping investigation to date, with Chinese PV panel exports to the EU amounting to around $8 \%$ of overall Chinese exports to the EU at that time (CEC 2012a). While the analysis was not made public, as is common in AD cases, interim duties were first imposed in June 2013 (CEC 2013).

Member states were divided on the issue, however: a majority of 18 of the 28 reportedly opposed these duties (De Gruyter 2014), including most notably Germany, which had been against the investigation throughout (Curran 2015; Oliver 2014; Yu 2013). This discord complicated a final imposition of duties and created the conditions for a very intense and more ideologically charged debate. In contrast to the US, where anti-dumping duties were imposed, the final agreement reached in the EU was for a so-called 'minimum price undertaking', which resulted in a price floor and a limit on market share-a decision supported by 22 member states (AFASE 2013c), but heavily criticised by ProSun. While the outcome reduced the flexibility for Chinese firms, the strong contestation and appeal by ProSun revealed its perception of who had 'won' and who had 'lost' the case. Following the July 2013 agreement, it submitted a formal appeal to the European Court and continues to monitor developments, resulting in the presentation of evidence of alleged infringement of minimum prices to the Commission as well as a request for an anti-circumvention investigation into alleged transhipment via Taiwan and Malaysia (ProSun 2015; SETI 2015).

The solar case thus became highly politicised, a contestation involving governments, business and their associations, although it did not really become a serious issue for public debate or for consumers. Even before any conclusions were reached, the Chinese government reacted strongly to the investigation and instigated parallel antidumping cases against the EU (especially regarding polysilicon, just after the launch of the case and wine, after the initial conclusions), thus implicating other companies, sectors and related countries. This move illustrates the tendency, confirmed in empirical studies, for many AD cases to be instigated in retaliation (Feinberg and Reynolds 2006; Prusa and Skeath 2001), with the consequence that fear of retaliation is an important factor in EU member states' voting decisions (Nordström 2011).

A legal peculiarity relevant to this specific case (and to the ideological nature of some of the arguments) is that the EU and the US treat China as a so-called non-market economy (NME) for anti-dumping investigations. Even though the protocol of China's accession to the World Trade Organisation enables market-economy status (applied by many other countries), the EU does not yet consider China to have fulfilled the requirements (CEC 2012b; EP 2012). This classification matters to China. Being cast as an NME is seen as a hindrance to the country's global economic ambitions and the government vehemently advocates change (Halper 2010; Ding 2011; $\mathrm{Yu}$ 2013). Moreover, as firms from an NME can more easily be targeted in AD investigations, Chinese MNEs are disadvantaged, casting a shadow over their capacity to develop global markets (Hou and Ren 2006).

China is the country targeted most often in EU antidumping procedures: of the $117 \mathrm{EU} \mathrm{AD}$ measures in force at the end of 2011, 53 involved China (next most affected were India and Thailand with 7 each; CEC 2012b). Chinese scholars have highlighted the ideological underpinnings of the NME status, which they consider a 'political tool', even questioning whether $\mathrm{AD}$ investigations can be objective in democracies. "In the multi-party, election-based democracies, politicians normally pay too much attention to the voice of unions and lobby groups... However, consumers' loss is ignored in the system..." (Hou and Ren 2006, p. 79). Thus, on both sides, the status of Chinese MNEs in AD seems underpinned by ideological differences. Although such divergence between home and host attitudes is of course not a new challenge for Chinese MNEs (Kolk 2010b), the stakes are particularly high in AD investigations.

In terms of the actors, SolarWorld played a prominent role in the EU and in the US in the respective ad-hoc industry groups that filed complaints on dumping; in both regions, counter-alliances were also created to lobby against the duties. As mentioned in the previous section, EU ProSun launched the case in the EU, with AFASE as the opponent; these two coalitions, established in 2012 even before the investigation started, were the key business actors. $^{2}$ The European Photovoltaic Industry Association (EPIA) chose to remain neutral, as did intermediary producers that supplied firms on both sides of the divide. While AFASE has been relatively open about its membership (see below), ProSun deliberately refrained from disclosing details. Its website contains a "statement on anonymous supporters" that clearly reveals the overall positioning: "Unfortunately companies who take a public stance against China are sometimes targeted by the authorities there. As EU Trade Commissioner Karel de Gucht recently stated, 'It is undeniable that many European companies are unwilling to come forward and make justified trade defence complaints due to fear of consequences for their business'. Hence the European

\footnotetext{
${ }^{2}$ In the US, the Coalition for Solar Manufacturing filed the complaint, and the Coalition for Affordable Solar Energy lobbied against the duties.
} 
Table 2 Timeline of the EU solar anti-dumping investigation (with US developments as reference information)

\begin{tabular}{|c|c|c|}
\hline Date & EU key events & US key events \\
\hline October 2011 & & $\begin{array}{l}\text { Coalition of US solar panel makers, led by SolarWorld, file } \\
\text { anti-dumping case against Chinese solar cells and panels } \\
\text { with the US Department of Commerce }\end{array}$ \\
\hline November 2011 & & US investigation launched \\
\hline May 2012 & & $\begin{array}{l}\text { Preliminary findings of dumping margins of between } \\
31.14-249.96 \%\end{array}$ \\
\hline July 2012 & $\begin{array}{l}\text { EU ProSun (also led by SolarWorld) files a complaint to the } \\
\text { European Commission against Chinese exports of solar } \\
\text { wafers, cells and panels }\end{array}$ & \\
\hline September 2012 & European Commission initiates EU investigation & \\
\hline October 2012 & & Definitive duties of $18.32-249.96 \%$ imposed \\
\hline June 2013 & $\begin{array}{l}\text { Provisional duties of } 11.8 \% \text { imposed until August 2013. In } \\
\text { case an agreement would be lacking by then, duties to be } \\
\text { increased to } 47.6 \%\end{array}$ & \\
\hline July 2013 & $\begin{array}{l}\text { Agreement announced between Commission and the key } \\
\text { Chinese exporters on a minimum price undertaking and } \\
\text { quota limitation }\end{array}$ & \\
\hline \multicolumn{3}{|l|}{$\begin{array}{l}\text { ProSun files } \\
\text { challenge in } \\
\text { European Court }\end{array}$} \\
\hline December 2013 & & $\begin{array}{l}\text { SolarWorld files new case against exports of certain Solar } \\
\text { cells and panels from China and Taiwan with US } \\
\text { Department of Commerce }\end{array}$ \\
\hline January 2014 & & Second investigation launched \\
\hline July 2014 & $\begin{array}{l}\text { ProSun indicates that it has submitted over } 1500 \text { proposals } \\
\text { by Chinese solar companies offering prices below } \\
\text { minimum level agreed by EU and China }{ }^{\mathrm{a}}\end{array}$ & $\begin{array}{l}\text { Preliminary findings of dumping margins of between } \\
26.33-165.04 \%\end{array}$ \\
\hline
\end{tabular}

a According to ProSun (2014a): "The European Commission has said it is investigating this claim, but nothing has been done yet against these illegal practices". In May 2015, however, the Commission proposed to withdraw three Chinese companies from the undertaking, making them subject to AD duties (SETI 2015). ProSun's court challenge against the agreement is still under way, although it is unlikely that there will be an outcome before the end of 2015 (SETI 2014)

Commission accepts confidentiality in filing trade complaints, and most of EU ProSun supporters wish to stay anonymous." 3 Although impossible to verify, SolarWorld (2012) claimed that the majority of the industry backed the complaint. Interview data indicate that ProSun supporters generally had limited links to the Chinese market. This was also said to apply, most notably, to SolarWorld itself.

\footnotetext{
3 http://www.prosun.org/en/about/mission.html (last consulted 9 December 2014); emphasis in original. Interestingly, the quote in italics is derived from a speech of the then trade commissioner, related by Chaffin (2012) and Evans (2012) to a possible EU investigation into alleged dumping by the Chinese telecoms companies Huawei and ZTE. Had it been launched, this would have been the first case pursued by the Commission in the absence of a formal complaint by business actors. Although referring to a different situation and another sector, ProSun nevertheless used it to support its own position. The telecoms case was never launched, partly because leading EU companies were reported to "not want a trade war with China" (Oliver 2014), but it did affect the solar case as its threat influenced the overall approach of the Chinese government.
}

AFASE maintained a full list of supporters and their country of origin on its website. It was dissolved as a separate entity on 31 October 2013 and integrated into SETI (the Sustainable Energy Trade Initiative Alliance, an industry coalition initiated and hosted by the International Centre for Trade and Sustainable Development, ICTSD, in Geneva). AFASE consistently mentioned the number of supporters, with 850 as the final count, to characterise itself as "a coalition of over 850 companies in the European Photovoltaic (PV) industry. We work to prevent protectionism in the sector and promote the benefits of free trade for solar energy products". 4 This formulation does not imply that all companies were 'European' in terms of head office; several were not. Nine Chinese companies were listed on AFASE's website in November 2012, including most notably Trina Solar and Yingli (the two largest solar PV firms worldwide at this point). Non-EU members accounted for $23 \%$ of the total then, including not only

\footnotetext{
${ }^{4}$ http://afase.org/en/mission (last updated October 2013).
} 
Chinese companies but also six from the US and one each formally from Canada and Pakistan (although the Canadian firm appeared to have all of its manufacturing facilities in China and the one from Pakistan seemed to be an American company with an important Chinese partner). However, the nationality and number of firms varied considerably over time. As AFASE developed, most of the Chinese firms dropped out. By March 2013, the two Chinese firms that remained-Trina Solar and Yingli-were listed as Swiss. Three months later, both had disappeared from the list of members, even though Trina Solar (2013) continued to make public statements against the duties. In June 2013, only $3 \%$ of AFASE members were non-EU firms, although by then there were members from all 28 member states.

All informants we spoke to concur that a key actor in the inception of AFASE was Trina Solar, a private Chinese company based in Changzhou, founded in 1997 and listed on NYSE and Nasdaq in 2006. Trina Solar's sales have historically been strongly focused on the European market, although its importance declined from $93 \%$ in 2009 to $68 \%$ in 2011, concurrent with an increasing presence in the US, accounting for $22 \%$ of sales in 2011 before the US AD case restricted market access (Trina Solar 2012). Its total sales increased from $\$ 845$ million to $\$ 2048$ million over the same period, although profits fell from $\$ 96$ million to a loss of $\$ 38$ million in 2011. The company attributed this to deteriorating market conditions, including declining government support. Trina Solar has an extensive network of sales offices and regional headquarters in Europe (Zurich), North America (San Jose) and South East Asia (Singapore). When we first spoke to Trina Solar's representative in Brussels, the firm was unambiguous about its important role in AFASE. Over time, however, its involvement in the alliance dwindled and finally ceased in June 2013. The Trina employee who was the key spokesperson for AFASE for the first few months of their operations was replaced in January 2013 by two European representatives of the public relations consultancy G Plus.

Yingli Solar was the other key Chinese firm involved in the case. Based in Baoding, Hebei Province, where most of its manufacturing takes place, it is also a private company, quoted on the NYSE, although it has a joint venture in China with Tianwei Baobian, a state-owned manufacturer of large electricity transformers. Yingli was a member of AFASE since its inception in summer 2012, until June 2013 when, like Trina, it withdrew from the alliance. Although was not as active as Trina, the company noted the importance of the issue, for example in the annual report (Yingli 2015, p. 11): "While we were exempted from paying any antidumping and anti-subsidy duties to the EU starting from August 6, 2013, increased sale prices and reduced consumption in the European market under the Undertaking may bring significant uncertainties to our business in the European market".

How many external resources were mobilised by AFASE itself to develop and implement its strategy and how many of those resources came from Chinese firms has been impossible to establish. Throughout 2014, neither AFASE, nor the European companies directly involved in the board, or AFASE's official PR company-G Plusdeclared their lobbying activity on the solar panel case under the EU's transparency register of lobbyists. In midNovember 2014, G Plus finally provided details of its clientele for 2013, which included the AFASE members Trina, Yingli and Suntech from China, as well as Canadian Solar and the British installer Solar Century. All were indicated as clients representing a turnover of less than $€ 50,000$. Trina Solar also registered individually and indicated that that they spent $€ 50-100,000$ annually, a figure that seems rather low given the level of their activity in Brussels when the case was being debated. Kreab Gavin Anderson, another PR company in Brussels, listed Trina Solar as a client, but indicated that spending on their services was under $€ 50,000$ (CEC 2014). In the later months of the campaign, the firm disappeared from the public lobbying radar. Press releases quoted mainly the CEOs of the three board members of AFASE, who are Dutch or German (e.g. AFASE 2013b).

\section{Arguments Used in the Case: Exploring Ideologies}

The preceding overview of key developments and actors has already provided the background to some of the most prominent arguments used in this highly contested case. This section will explore these in more detail and also highlight their ideological nature where applicable. In the solar panel case, arguments focused on job losses and employment numbers, the importance of renewables in the context of sustainability, cost and affordability of solar, and the issue of government support. Table 3 contains some illustrative quotes and views from both AFASE and ProSun, including assertions of a more ideological nature on the various aspects.

In terms of the more ideologically charged arguments, the ProSun statement quoted above referring to company confidentiality and fear of retaliation explicitly mentioned the role of China, i.e. its government. This framing of Chinese companies as inseparable from the Chinese state pervaded the arguments used by ProSun (and by SolarWorld). Sometimes it was left (largely) implicit, for example when emphasising the loss of European jobs, of the EU's technological and market position in solar, and of its long-term energy security. Frequently, however, these aspects were linked to China 'taking over' the sector, a 


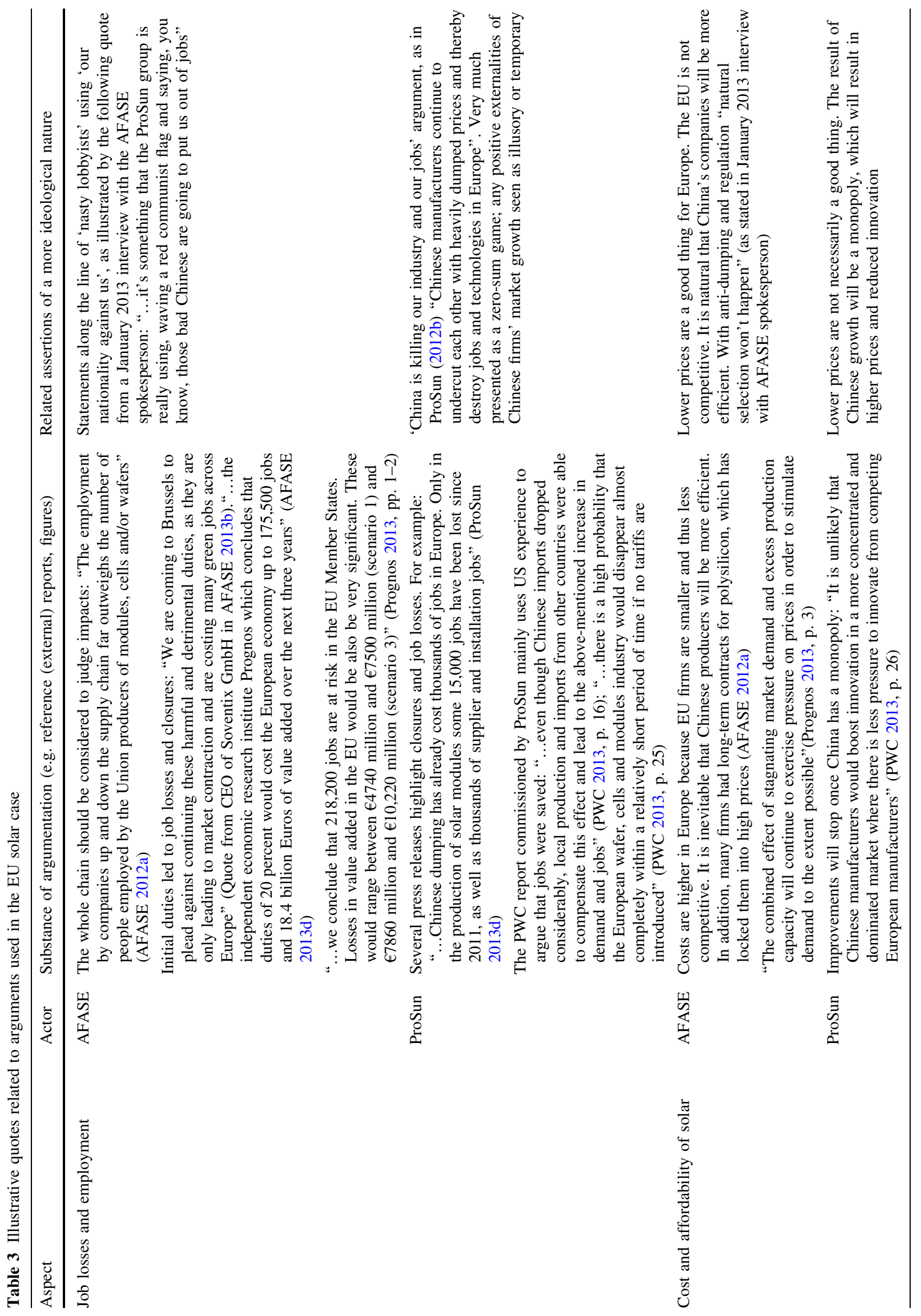




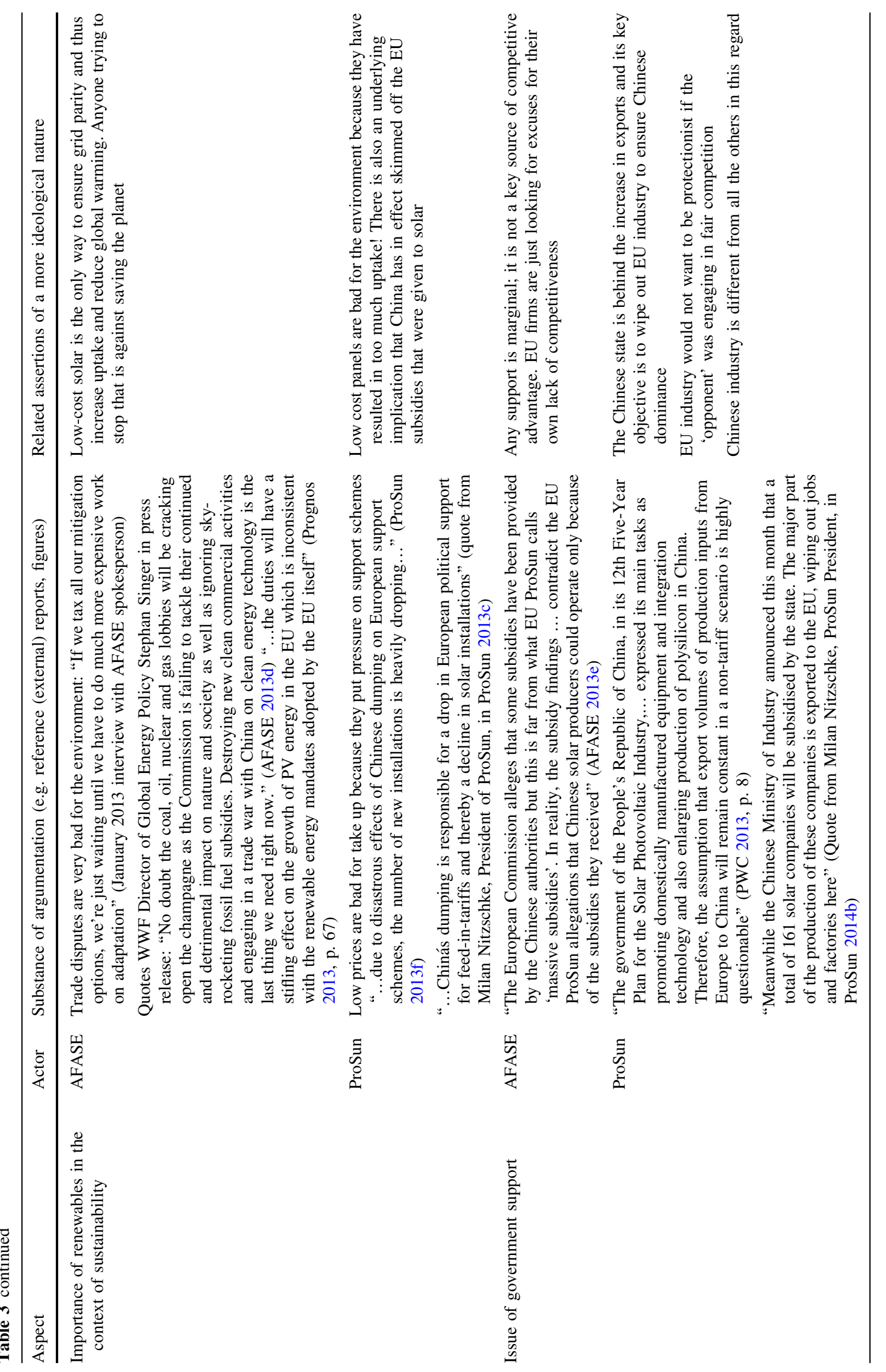


policy instigated directly by its government, or indirectly through Chinese firms (with AFASE as 'front organisation'), and the need for the EU to draw a line in this case to signal action against the more generic 'China threat' beyond the solar sector. As ProSun (2013d) put it, "From steel production to the automobile industry, no one can be certain to be able to obtain redress against even the most flagrantly illegal subsidised dumping by producers from third countries. For Europe's industrial base, this would be devastating". In a sense, ProSun's argument was helped by the legal status of China as an NME, given the country's persistent failure to qualify as a market economy, reflecting a wider difficulty in acceptance of the Chinese economic model abroad (Halper 2010), as also noted in an EU report “...there is no denying that some of China's industrial and macro-economic policies imply an approach based on state capitalism." (CEC 2010, p. 5).

Chinese firms in the dispute sought to distance themselves from the state apparatus and underlined their private status, insisting that they were competing in the EU on a level-playing field, as part of an industry that is global in nature, with firms from a range of nationalities spread over the whole supply chain. Nevertheless, the fact that their home country is labelled an NME means that they are inevitably disadvantaged, both in arguing their case and concretely in the manner in which $\mathrm{AD}$ investigations are conducted (Hou and Ren 2006; Liu 2005). This also enabled ProSun to cast them as representative of a different type of competition. As a spokesperson mentioned during an interview in August 2013, "European companies are not afraid of competing with Korean or Japanese or Americans or whoever, but they can't compete with China, because China has this incredible state support". Thus, ProSun clearly presented the priorities of the Chinese government and of its exporting firms as one and the same (referring to AFASE as a "Chinese lobby group" (ProSun 2013c). AFASE obviously felt the need to respond to these charges. Indications of this include its evolving membership, examined above, in terms of nationalities and dwindling involvement of Chinese firms, and its disbandment and integration into the well-respected SETI (see next subsection). ProSun (2013a) cast an ever wider net, however, in the firms they targeted, implying that all those involved in AFASE were suspect, "Chinese solar manufacturers are backing a European front group of installers who use their products called AFASE".

ProSun's statements became most ferocious and ideologically oriented after the minimum price undertaking was concluded in July 2013, with attacks on Chinese producers and others involved in the trade in solar panels (labelled "shady middlemen") and even on the EU authorities. Examples include the accusation that "Chinese solar manufacturers, illegal [sic] subsidised and state financed, sell their products in Europe far below production costs" and "Chinese manufacturers never cease to trick, deceive and circumvent their own undertaking and EU rules" (ProSun 2013d, 2014a). The EU authorities were portrayed as passive bystanders at best and, at worst, as extremely weak and complicit in undermining the industry. According to ProSun (2013d): "Throughout the negotiations, China appears to have blackmailed and mocked the EU". This unequal relationship apparently continued into the administration of the minimum price undertaking. When the Chinese government requested a revision to the minimum price to reflect currency evolution, ProSun stated (2014b) that "Beijing gave Brussels 'an offer they could not refuse' increasing injury to European industry and neutering EU trade defence measures". This was presented as "currency trickery" and heavily criticised: "DG Trade has already forwarded China's proposal to other services for rubber-stamp approval, and intends to gloss over it as a technicality in a meeting with EU Member States" (ProSun 2014b).

There were also more economically grounded concerns in Europe about the specific threat posed by the growth and spread of EMNEs, a phenomenon discussed more generally in relation to the established position of western firms on their home markets (Kothari et al. 2013; Kumar et al. 2013). However, these also had an ideological dimension, as the issue of 'how' support is garnered in different countries has been fundamental to much of the debate in this case. As noted above, the EU mostly focuses on subsidisation of the uptake of renewable energy on the buyer side, whereas government support in China has mainly taken the form of support for production, as part of a broader effort to move up the value chain to more innovative manufacturing (Dunford et al. 2013; Grau et al. 2012; Haley and Haley 2013; Nahm and Steinfeld 2014; Zhang et al. 2013). As such differential support systems have divergent impacts in economic, political and environmental terms, they paved the way for a debate on what counts as 'fair' government support for realising societal goals. As Haley and Haley (2013) point out, although most economists regard trade protection as an inefficient and distortive tool, some have argued that in cases of government production subsidies and asymmetric market access the reaction of MNEs to seek protection is perfectly rational. There is thus some intellectual underpinning to the ideological arguments for protection which emerge in this case.

Interestingly, while the literature on LOR also refers to the use of negative perceptions of the products/service from a specific country (Ramachandran and Pant 2010), this aspect was rarely highlighted in our case. ProSun mentioned the lower quality of Chinese panels during an interview, and could have used it for stereotyping and 
promoting fear and distrust. However, it did not really play a role in the public discourse. Perhaps ProSun felt it had insufficient evidence to come out with firm public statements as many of those interviewed (including EPIA and SETI) see solar panels as a mere commodity, with little difference between products. Still, ProSun argues that they differ from basic commodities on the grounds that, unlike mobile phones, solar panels need to continue working for over 20 years (ProSun 2013a).

There is, however, little objective evidence that Chinese panels are sub-standard. Several in-depth studies of the Chinese solar sector indicate that many firms have successfully reached technological equivalence with Western producers (Dunford et al. 2013; Nahm and Steinfeld 2014; Quitzow 2015). In their analysis of the evolution of the key Chinese solar companies, Dunford et al. (2013) describe how Chinese industry - through a combination of imported machinery, repatriated skilled scientists and acquisitionsmanaged to develop capacities very rapidly. Quitzow (2015) describes similar strategies, highlighting how Chinese firms have benefitted from substantial technology transfer from German solar panel producers and equipment manufacturers. He argues that this technology transfer, together with indigenous innovation, take-overs and returnee scientists, have enabled the companies to overcome initial customer distrust. Nahm and Steinfeld (2014) similarly argue that Chinese firms have combined international technology with unique domestic capacity to develop cutting-edge solar and wind capacities.

In addition to the more ideologically charged arguments explored above, protagonists of the duties used traditional economic arguments concerning the negative impacts of low-price imports, a common strategy in dumping disputes (see, for example, the analysis of the EU case against Chinese and Vietnamese footwear in Eckhardt 2011). The arguments used in the solar panel case differed little from those in previous anti-dumping disputes, regardless of the ideological underpinning of the country of origin. They reflect the legal reality that, for anti-dumping duties to be imposed there must be evidence, not only that dumping has taken place, but also that it has caused 'material injury' to local industry (CEC 2012a). In this context, the focus is not on the nature of the competition, as in the ideological arguments outlined above, but on the socio-economic implications.

Thus, a very prominent argument used by ProSun involved the negative economic impact of imports on the EU solar panel industry, especially concerning job losses. On its website, ProSun kept a list of EU companies that had become insolvent or ceased solar production to help establish the harm caused by Chinese dumping (Prosun 2013b). Interestingly this list also included companies that had been taken over by Chinese investors. AFASE's generic response was to point to the fact that most solar employment and value creation was in Europe if one includes both upstream and downstream jobs in the EU PV industry (polysilicon, ancillary inputs, machinery and the installation sector). It also argued that EU production of intermediate products for the solar sector was very important and that instigating anti-dumping duties would increase prices in the EU, thus reducing demand for both the final product and these intermediate inputs, and creating a 'boomerang' effect in Europe (AFASE 2012b).

To provide further counter-evidence, AFASE commissioned an external Swiss consultancy, Prognos, to examine the economic implications. The resulting report stressed the very negative effects of possible anti-dumping duties in terms of both job losses and value creation in the EU (see Table 3). Germany was expected to suffer the most (Prognos 2013; cf. Curran 2015). To be able to reply as effectively as possible, ProSun engaged Price Waterhouse Coopers (PWC), resulting in a report that was highly critical of Prognos' methodology and claimed that antidumping duties would in fact increase local employment, although, in contrast to the Prognos study, it did not seek to calculate exact figures (PWC 2013). Although primarily based on economic analysis, the report also stressed the wider context, particularly the Chinese government's fiveyear plan, to which ProSun press releases also referred (see last row in Table 3). A key point was that China's objective was not only to develop the solar panel industry, but the whole value chain (ProSun 2013e). We thus see very different 'stories' emerging from the two camps, which served to underscore their relative positions (Fine and Sandstrom 1993).

Further economic arguments marshalled by ProSun included the accusation that Chinese producers were striving for a monopoly position on the EU market and, once that had been realised, innovation would cease and prices would go up again. Although there is evidence that R\&D spending in Germany fell as difficulties in the sector increased (Blau 2013), this argument sits uneasily with recent academic studies of the PV sector in China. They indicate that firms in this sector have developed quite unique innovation capabilities precisely through exploiting their international customer and supplier links, such that they are just as reliant on their international partners, including those in Germany, as the latter are on them (Nahm and Steinfeld 2014; Quitzow 2015). AFASE saw such complaints by European firms (and ProSun) as illustrating the fact that they were not able to face competition and therefore were ideologically biased in favour of protectionism, not free trade.

The nature of the product in question also provided the opportunity to mobilise wider environmental arguments. Through its website and position papers, AFASE often 
referred to the potential negative impacts of anti-dumping duties on the uptake of solar power in Europe. A salient, related aspect in this regard, included in Table 3, concerns the reduction in panel prices resulting from Chinese imports. AFASE emphasised the positive effects of lower prices, for Europe in general and for consumers and sustainability in particular, as it would promote the spread of renewables: "The increased use of solar energy hinges on solar energy being competitive with other sources of energy... The imposition of anti-dumping measures is blatantly inconsistent with this goal" (AFASE 2012a).

ProSun developed a circuitous argument to justify how low prices were bad for the environment. It invoked the risk that high uptake of solar would increase pressure on subsidy systems to such an extent that political support for schemes would collapse. A ProSun (2013e) press release accused Chinese producers of undermining EU support systems for green energy by providing too much low-cost supply: "China flooded the European solar market with dumped modules, overburdening European support schemes". AFASE (2013f), however, countered that the phasing out of support schemes is inevitable and has nothing to do with cheap imports: "If some EU manufacturers of solar products have been complacent and expected public support schemes to stay in place for a long time and to keep prices for solar products and profitability high, they should blame themselves".

The arguments in the case were picked up by environmental campaigners. A group of NGOs, headed by WWF, issued a position paper in May 2013 in which they strongly opposed anti-dumping duties on Chinese imports. They highlighted the negative employment effects forecast in the Prognos report, but also the impact on the EU's long term environmental goals: "This move by the Commission [proposing interim duties] questions the continued pathway to a clean and renewable energy economy in Europe" (WWF 2013). Moreover, they questioned the argument that Chinese solar production was only for export and that China itself was not acting on global warming: "Fact [sic] is that China has one of the most ambitious targets for domestic PV installations". By linking the outcome of the case to the negative implications for both EU employees and the environment, the NGO statement underlined the fact that the interests of the EU at large would not be best served by restricting imports. This provides an alternative ideological framing to that proposed by the supporters of duties i.e. it stresses global public goods and the need to put environmental objectives before economics (Fine and Sandstrom 1993; Garmann 2014).

AFASE referred to the WWF report in a press release (see Table 3) as an unsolicited external party's view that strengthened their position. ProSun, on the other hand, was scathing about the involvement of NGOs in the case. In an interview, the spokesperson stated they had fundamentally misunderstood the threat from the Chinese PV industry and had, in effect, been misled by AFASE, whose focus on environmental impacts obscured wider political and economic goals. Remarkably, the campaign by NGOs and others solicited a Commission riposte early in the investigation stating that "... a market that faces dumped imports will drive local producers out of business and could discourage EU producers from developing cutting edge technologies in the renewable energy sector" (CEC 2012c). Such a spontaneous defence of the anti-dumping system is unusual and underlines the pressure felt and the importance of the issue.

\section{Discussion}

As the preceding analysis has shown, faced with the challenge posed by the solar panel case, the targeted Chinese MNEs responded in different ways. We found evidence of some of the strategies identified in existing literature which emerged from the study of deep presence through FDI, usually by developed-country MNEs. Sometimes the EMNEs in our study tailored their actions to the specific situation. Furthermore, rather novel approaches seemed to be at play, perhaps due to the ideological nature of criticisms and to the EMNEs' LOR. Table 4 presents an overview of the different strategies that emerged from both sides of the debate, the tactics and actions taken to achieve these strategic objectives and an indication of whether they (mostly) address LOF and/or LOR.

The solar panel dispute highlighted liabilities of Chinese PV exporters related to their newness in the market, perceived lack of legitimacy and trust, concerns about the loss of EU technological superiority and jobs, and the framing of these firms as 'agents' of a foreign state, acting in concert with the governments' five-year plan. This latter point was a key element in their LOR, augmented by the legal reality of NME for China and Chinese MNEs. The overall objective of the EMNEs' strategies in this case included strengthening localisation and 'embeddedness', as identified in previous work (Daamen et al. 2007). Tactics included the acquisition of expertise to reduce unfamiliarity, exemplifying the 'buying-in' of required resources to reduce LOF (and LOR) (Daamen et al. 2007), as well as the creation of networks with European firms and stakeholders and the gradual favouring of these partners in media presentations.

Both AFASE as a group and the Chinese MNEs were active in promoting their key messages (see Table 4). In terms of LOR, the Chinese firms were more active, as could be expected from the peculiarities of their situation. While AFASE lobbied on the basis of 'community 
Table 4 Strategies and tactics to address LOF and/or LOR

\begin{tabular}{|c|c|c|c|}
\hline Strategy & Tactic/action & $\begin{array}{l}\text { Addressing } \\
\text { LOF or LOR }\end{array}$ & Adopted by \\
\hline \multirow[t]{3}{*}{$\begin{array}{l}\text { Establish material harm to the } \\
\text { EU }\end{array}$} & Provide specific indications of lost EU jobs and innovation & $\begin{array}{l}\text { LOF and } \\
\text { LOR }\end{array}$ & ProSun \\
\hline & Sponsor 'objective' empirical analysis & LOF & ProSun \\
\hline & Highlight threat to EU energy security & LOR & ProSun \\
\hline \multirow[t]{3}{*}{ Marshal 'China Threat' fears } & Undermine legitimacy of Chinese market actors; 'shady middlemen' & LOR & ProSun \\
\hline & Conflate Chinese companies with the state; 'Chinese dumping' & LOR & ProSun \\
\hline & $\begin{array}{l}\text { Highlight Chinese involvement in AFASE, a 'front group', as indicative of a } \\
\text { lack of legitimacy }\end{array}$ & LOR & ProSun \\
\hline \multirow{3}{*}{$\begin{array}{l}\text { Use political and legal } \\
\text { avenues to secure } \\
\text { protection }\end{array}$} & File complaint to the European Commission and lobby for political support & $\begin{array}{l}\text { LOF and } \\
\text { LOR }\end{array}$ & ProSun \\
\hline & Appeal against the minimum price undertaking & $\begin{array}{l}\text { LOF and } \\
\text { LOR }\end{array}$ & ProSun \\
\hline & $\begin{array}{l}\text { Provide regular details of alleged breaching of the undertaking to the } \\
\text { Commission and issue press releases accusing Chinese government and } \\
\text { exporters of bad faith }\end{array}$ & $\begin{array}{l}\text { LOF and } \\
\text { LOR }\end{array}$ & ProSun \\
\hline \multirow[t]{2}{*}{$\begin{array}{l}\text { Marshal concerns on } \\
\text { economic effects of duties }\end{array}$} & $\begin{array}{l}\text { Provide detailed estimates of supposed job losses in the event that duties were } \\
\text { imposed }\end{array}$ & LOF & AFASE \\
\hline & Sponsor 'objective' empirical analyses & $\begin{array}{l}\text { LOF and } \\
\text { LOR }\end{array}$ & AFASE \\
\hline \multirow[t]{2}{*}{$\begin{array}{l}\text { Marshal fears on } \\
\text { environmental impacts }\end{array}$} & $\begin{array}{l}\text { Underline environmental protection objectives and contribution to broader } \\
\text { public goods }\end{array}$ & $\begin{array}{l}\text { LOF and } \\
\text { LOR }\end{array}$ & $\begin{array}{l}\text { AFASE; } \\
\text { Chinese } \\
\text { MNEs }\end{array}$ \\
\hline & Endorse arguments brought forward by local NGOs & $\begin{array}{l}\text { LOF and } \\
\text { LOR }\end{array}$ & AFASE \\
\hline \multirow[t]{4}{*}{$\begin{array}{l}\text { Strengthen local } \\
\text { embeddedness }\end{array}$} & Acquire local knowledge (e.g. PR companies, lawyers) & LOF & $\begin{array}{l}\text { Chinese } \\
\text { MNEs }\end{array}$ \\
\hline & Create alliances with local suppliers, customers and other stakeholders & $\begin{array}{l}\text { LOF and } \\
\text { LOR }\end{array}$ & $\begin{array}{l}\text { Chinese } \\
\text { MNEs }\end{array}$ \\
\hline & Prioritise use of local spokespeople & $\begin{array}{l}\text { LOF and } \\
\text { LOR }\end{array}$ & AFASE \\
\hline & Reduce number of Chinese member firms; increase EU membership & LOR & AFASE \\
\hline \multirow[t]{2}{*}{ Showcase familiarity } & $\begin{array}{l}\text { Emphasise private status of companies (i.e. listed on stock exchange, not } \\
\text { related to state apparatus) }\end{array}$ & LOR & $\begin{array}{l}\text { Chinese } \\
\text { MNEs }\end{array}$ \\
\hline & Highlight inherently international nature of the industry & $\begin{array}{l}\text { LOF and } \\
\text { LOR }\end{array}$ & $\begin{array}{l}\text { AFASE; } \\
\text { Chinese } \\
\text { MNEs }\end{array}$ \\
\hline \multirow[t]{2}{*}{ Harness policy relations } & Negotiate agreement with European Commission & LOF & $\begin{array}{l}\text { Chinese } \\
\text { MNEs }\end{array}$ \\
\hline & Take retaliatory anti-dumping action & LOF & $\begin{array}{l}\text { Chinese } \\
\text { government }\end{array}$ \\
\hline
\end{tabular}

interest', the Chinese MNEs sought to showcase their familiarity by distancing themselves from their home government and underlining their credentials as private companies established by individual visionaries unrelated to the state apparatus-i.e., 'normal' capitalist companies listed on the stock exchange. In a similar vein, they also stressed the international nature of the sector and how difficult it was to put a nationality on a product. Their rhetoric reflected free market ideology and emphasised the benefits of globalisation. This point was echoed in AFASE's position papers and especially in the Prognos report, with its emphasis on the symbiosis between cheap panels and job creation in the EU solar sector.

Some of the strategies adopted in this dispute are rather novel, especially the strengthening of local embeddedness through the creation of the ad-hoc group (AFASE). Although conceptually anticipated by Eden and Miller (2009) and McGuire et al. (2012), actual cross-regional 
lobbying initiatives are rare. The AFASE website provided a very sophisticated lobbying platform, including model letters to decision-makers, training on the issue for firms and detailed argumentation challenging the anti-dumping case. Strategically it clearly represented an attempt by Chinese companies to increase their legitimacy by localisation of lobbying activities as they sought to become 'insiders' (Eden and Miller 2009), and link their interests to those of host-country actors. It is also an example of institutional entrepreneurship in reaction to LOR (Ramachandran and Pant 2010), as the Chinese firms that initially launched AFASE were quite successful in establishing a wide consortium covering all EU member states. Interestingly, we also found that they changed their strategy over time in view of the perceived foreignness of the founding membership, which resulted in LOF, or, in AFASE's case, LOR. Thus, achieving a local embeddedness required a localisation of the alliance.

This was particularly mirrored in the presentation and composition of AFASE's membership, as discussed in the findings section. In an interview in November 2013, a representative conceded that once a wide selection of EU companies had been mobilised in the organisation “... we felt it was much better to go as $100 \%$ branded Europeans...", and also admitted that Chinese involvement “...wasn't a huge barrier, but it wasn't helping us". The change thus seemed to be a direct reaction to criticisms from ProSun, which constantly drew attention to the involvement of Chinese firms, in order to marshal fears of a 'China threat'. Thus, in spite of already having a wide membership, the AFASE group was politically disadvantaged by the involvement of 'foreign' companies in its grouping. Specifically its Chinese members were represented as ideologically suspect, reflecting LOR. Even after the public changes in membership and home-country affiliation, ProSun continued (2013c) to use the 'front group' label whenever possible, referring to "...the Chinese-backed lobbying group AFASE” (see Table 4).

The link made between the imposition of anti-dumping duties on cheap solar panels on the one hand and the EU's sustainability objectives and the related broader 'public good' on the other is also notable. Local environmental NGOs mobilised in support of the Chinese exporters in this regard, helping to marshal fears that duties would have a negative effect on environmental objectives. The joint statement of several well-respected NGOs, including WWF, against the duties, provided a level of legitimacy to AFASE's perspective that its own PR machinery could not achieve. The NGO involvement embodied the use of 'stakeholder support resources' (Dahan 2005), providing wider legitimacy for AFASE's objectives and representing an enhancement of reputation and reliability in the local setting (Klossek et al. 2012). The fact that the arguments were made by NGOs, rather than the interested firms, gave them added weight. It also signalled that the Chinese MNEs were contributing to wider societal goals, which enabled them to appear more socially responsible than their detractors. This was important to them, since, as outlined above, Chinese MNEs often face challenges abroad in relation to CSR (Kolk 2010b). Furthermore, the move to merge AFASE into SETI was not an arbitrary choice. SETI $(2014,2015)$ continues to provide updates and press releases on the case, including updates on the minimum-price undertaking and of progress on ProSun's call for investigation of alleged contravention (see Table 2). SETI and its host institution ICTSD are funded, inter alia, by governments (including Norway and the UK) and multilateral institutions (including WTO and UNEP), which renders them less ideologically suspect than private lobby groups.

Finally, in addition to the relatively sophisticated strategies of the Chinese firms within their host region, there is also evidence that they harnessed their political contacts. Although Chinese exporters faced liabilities because of their origin, this fact also strengthened their situation. Their home government was important from the beginning, as early press reports refer to veiled threats of retaliation from Chinese officials (Chaffin and Wiesmann 2012) and actual retaliation was forthcoming in the form of an anti-dumping case against polysilicon, which especially affected German business (Lewis 2014). Once the decision to impose provisional anti-dumping duties was taken, diplomatic activity by China seemed to increase further, with observers indicating that member states were pressured to reject the proposal, putting the Commission on the defensive (Chaffin 2013; De Gruyter 2014; Evenett 2013). A Chinese spokesman formally denied this in a press conference, stating that member states' positions were simply based on common sense (Chinese Mission 2013). Still, it is undeniable that the launch of a retaliatory anti-dumping investigation against EU wine and the apparent threat of a new case against German cars had an effect on EU governments (Chaffin 2013). Moreover, it drew in a new set of EU actors with a vested interest in an amicable settlement, who themselves helped to marshal fears on the potential negative impacts of duties on the EU economy. For example, the head of the French wine exporters association acknowledged in a press interview that he had lobbied French ministries against the solar anti-dumping duties (Compadre 2013).

\section{Conclusions}

This paper has explored the role of ideology in attempts to influence public policy and in business representation in the EU-China solar panel dispute. Our analysis of the evolution of this specific issue illustrates the complexities 
involved in the interaction between markets and ideologies in the midst of debates regarding different types of subsidy regimes for renewables, free trade versus protectionist tendencies by governments and sustainability objectives. We also examined the dynamics of the international activity of these Chinese MNEs in the EU, epitomising emerging-market versus developed-country tensions. This has shed light on the recent notion of 'liability of origin', in addition to the traditional concept of 'liability of foreignness' studied in international business research, in relation to firms' market and political strategies, and their institutional embeddedness in home and host countries.

The EMNEs were confronted with institutional frictions, including societal expectations and actor dynamics that diverged between their home and host contexts, which went beyond the "ethics away from home" dilemmas already discussed in the literature. In this case, public accusations about illegal practices, blackmailing, trickery and front groups were added to more traditional economically grounded concerns about the "destruction" of European jobs, factories and technologies, and sustainability considerations (see Table 3). ProSun portrayed the priorities of the Chinese governments and the exporting companies as one, highlighting a key difficulty mentioned by McGuire et al. (2012, p. 348) for EMNEs as being “...seen as essentially agents of government rather than commercial operations". This harnessing of rhetoric representative of a 'China threat' ideology resonated with media and academic concerns about the risk of the rise of China being accompanied by increasing strength of Chinese values on the global stage (Halper 2010, 2011).

The Chinese MNEs and AFASE, which supported their cause, adopted a range of strategies and tactics to counter their LOF and LOR, in reaction to ProSun (see Table 4). They became active participants in the public debate to defend their interests against a direct threat from the host region's institutions, marshalling diverse arguments and a range of local stakeholders in support of their case. While the institutional friction between home and host contexts directly impacted the Chinese firms involved, the combination of their strategies and support from the domestic government ensured an acceptable outcome. Their lobbying campaign was sophisticated and multi-level, using a variety of approaches which have been identified in the literature on corporate political activity, including buying in expertise, mobilising relational and organisational resources, and securing stakeholder support (Dahan 2005). Ideology played a role throughout the period covered by our study, but was most intense in the phase after the imposition of provisional duties and ProSun (2015) continues to use ideological arguments for action.

The manner in which the solar panel case evolved and the rhetoric around it have implications for theorising about how different types of liabilities influence MNEs in general, and EMNEs in particular. The Chinese MNEs sought to strengthen their local embeddedness in various ways, through buying-in of local expertise and attempts to integrate into local networks. Our findings thus provide evidence of the hypothesis formulated by McGuire et al. (2012) that coalitions of interest will develop when EMNEs' interests become aligned with those of local firms. It also shows that cross-country industry associations may help Chinese MNEs to be seen as insiders, as proposed by Eden and Miller (2009). Despite the novelty and relative success of collaboration with European firms and, notably, with NGOs, it should be noted that the efforts of Chinese MNEs to be seen as 'insiders' failed to some extent. The Chinese firms that initially mobilised ad-hoc resistance to the anti-dumping duties were replaced over time by representatives of local European companies. This rather extreme 'localisation' of the alliance, which finally saw all Chinese firms disappear from the membership listing, seems likely to be tied to the very specific difficulties they faced, linked to ProSun's tendency to conflate them with their home government.

It is thus not LOF but LOR that dominated in this context, as Chinese firms were more vulnerable in the EU not just because they were foreign, but because of their Chinese nationality. State ownership was not an issue, as the two largest firms-Trina Solar and Yingli-were private. However, the differences inherent in the economic model of their home country meant that these EMNEs were subject to greater discrimination hazards, including negative stereotyping, than other foreign firms (Eden and Miller 2009). The active role of the Chinese government in the economy was used by those who supported the duties to undermine the legitimacy of Chinese MNEs, in line with the 'China threat' ideology (see Table 3) in a rather similar manner to the way OPEC producers were painted as 'unethical' in the campaign to rebrand tar sand oil as 'ethical' (Haase and Raufflet 2012). In the end, however, the strong state also provided a context of active support for a negotiated 'amicable' settlement, and press reports and interviews with key actors indicate that the final outcome of the case was indeed impacted by the Chinese government. This active involvement of the home government was suggested as a necessary component for countering LOR (Ramachandran and Pant 2010) given that it is a country-related concept, and not firm-specific. Firm action alone would probably have been insufficient to adequately address the issue.

Although in this case the outcome was relatively favourable to the EMNEs, which in effect acted as institutional entrepreneurs (Ramachandran and Pant 2010), in general, LOR seems more difficult to address than certain types of LOF, such as unfamiliarity, which can be addressed through learning (Petersen and Pedersen 2002). 
Some discrimination in host settings may be generic to all foreign firms, but those from countries of origin with very different governance and institutions to the host country are likely to face specific barriers linked to ideological differences. The frequent highlighting of these differences by the local firms seeking protection in this case illustrates the enduring power of 'stories' to transmit values and underpin ideology (Wines and Hamilton 2009). At the same time, the Chinese firms presented their own 'stories' of entrepreneurial visionaries seeking to save the planet through free, fair and global competition. In this case, ideology can be viewed as "meaning in the service of power" (Chelli and Gendron 2013, p. 190), with both sides trying to use it to legitimise their positions and define what is 'normal'.

This study has helped to shed more light on these issues and the dynamics at play. China is amongst the most prominent emerging economies, and its economic and political importance means it is an illustrative case. At the same time, follow-up research, covering other cases, sectors and countries, would be helpful, as there were aspects that seemed peculiar to the 'Chineseness' of the MNEs involved and to solar panels. It should also be noted that dumping cases are typically highly sensitive, which imposed constraints on our ability to disclose interviewee names and to interview government representatives. While we could use reported positions in the press, seen as a reliable source in these cases (Evenett and Vermulst 2005), and a range of other sources, including interview data from both sides of the dispute, additional primary information might have had added value. Overall, however, while remaining modest in terms of our study's potential applicability beyond Chinese MNEs, we believe that the indepth investigation can inform our existing understanding of MNE strategy and the interactions between markets and ideologies, and provide useful building blocks for theory.

Acknowledgments The second author would like to acknowledge the support provided by the POREEN Marie Curie research network (www.poreen.eu).

Open Access This article is distributed under the terms of the Creative Commons Attribution 4.0 International License (http://crea tivecommons.org/licenses/by/4.0/), which permits unrestricted use, distribution, and reproduction in any medium, provided you give appropriate credit to the original author(s) and the source, provide a link to the Creative Commons license, and indicate if changes were made.

\section{References}

AFASE (2012a). Summary of the AFASE injury/Union Interest submission dated 29-10-2012. Alliance for Affordable Solar Energy. Retrieved from http://afase.org/en/action/anti-dumpingcomplaint?page $=1$.
AFASE (2012b). The global solar value chain. Alliance for Affordable Solar Energy. Retrieved from http://afase.org/en/globalsolar-value-chain.

AFASE (2013a). Global Market Situation. Retrieved from http:// afase.org/en/global-market-situation.

AFASE (2013b). "Solar duties are destroying European jobs!" European PV Companies come to Brussels to contest Commission rose-tinted findings on the impact of duties. Brussels, 16 July.

AFASE (2013c). Implications of the EU's acceptance of price undertakings by Chinese producer-exporters of modules, cells and wafers. Retrieved from: http://afase.org/en/media/priceundertakings-exempt-many-products-anti-dumping-duties.

AFASE (2013d). Proposed solar duties will severely hurt EU industry. Brussels, 4 June. Retreived from http://afase.org/en/ media/proposed-solar-duties-will-severely-hurt-eu-industry.

AFASE (2013e). European Commission issues proposed definitive findings on anti-dumping and anti-subsidy for commenting. Brussels, August.

AFASE (2013f). Provisional anti-dumping duties put at risk thousands of jobs and billions of value added to the EU economy. 12 May.

Algieri, B., Aquino, A., \& Succurro, M. (2011). Going 'green': Trade specialization dynamics in the solar photovoltaic sector. Energy Policy, 39(11), 7275-7283.

Avsar, V., Karayalcin, C., \& Ulubasoglu, M. A. (2013). State owned enterprises, inequality and political ideology. Economics and Politics, 25(3), 387-410.

Barnett, T., Bass, K., \& Brown, G. (1994). Ethical ideology and ethical judgment regarding ethical issues in business. Journal of Business Ethics, 13, 469-480.

Bass, K., Barnett, T., \& Brown, G. (1999). Individual difference variables, ethical judgments and ethical behavioral intentions. Business Ethics Quarterly, 9(2), 183-205.

Blau, J. (2013). Outlook cloudy for Germany's Solar R\&D. ResearchTechnology Management, 4-6.

Bowie, N. E. (1997). Ethical theory and business (5th ed.). Upper Saddle River, NJ: Prentice Hall.

Bowie, N., \& Vaaler, P. (1999). Some arguments for universal moral standards. In G. Enderle (Ed.), International business ethics. Challenges and approaches (pp. 160-173). Notre Dame, IN: University of Notre Dame Press.

Carbaugh, B., \& St. Brown, M. (2012). Industrial policy and renewable energy: Trade conflicts. Journal of International and Global Economic Studies, 5(1), 1-16.

CEC. (2010). Trade growth and world affairs. Brussels: Commission of the European Communities.

CEC (2012a). EU initiates anti-dumping investigation on solar panel imports from China. Press Release Ref: MEMO/12/647. 6 September 2012. Brussels: Commission of the European Communities.

CEC. (2012b). Commission staff working document accompanying the document 'Report from the Commission to the European Parliament 30th Annual Report from the Commission to the European Parliament on the EU's Anti-Dumping, Anti-Subsidy and Safeguard activities (2011)'. Brussels: Commission of the European Communities.

CEC (2012c). Why the EU's investigation into solar panel imports from China does not harm Europe's climate goals. Fact Sheet, 10 September. Brussels: Commission of the European Communities. Retrieved from http://trade.ec.europa.eu/doclib/html/ 149903.htm.

CEC (2013). EU imposes provisional anti-dumping tariffs on Chinese solar panels, Press release. 4 June 2013. Brussels: Commission of the European Communities. 
CEC (2014). EU Transparency Registrer. Retrieved from http://ec. europa.eu/transparencyregister/info/homePage.do?locale=en.

Chaffin, J. (2012). Beijing faces Brussels action on telecoms aid. Financial Times.

Chaffin, J. (2013). Karel De Gucht: Frustrated and outflanked. Financial Times.

Chaffin, J. \& Wiesmann, G. (2012). EU trade officials face China dilemma. Financial Times.

Chelli, M., \& Gendron, E. (2013). Sustainability ratings and the disciplinary power of the ideology of numbers. Journal of Business Ethics, 112, 187-203.

Chinese Mission (2013). Response of the spokesperson of the Chinese mission to the EU concerning the alleged 'pressure' exerted by China on EU member states on trade dispute. Chinese Embassy in Brussels, 30 May. Retrieved from http://www.chinamission. be/eng/sthd/t1045679.htm.

Choudhury, N. (2013). Unravelling the China-Europe trade war. $P V$ Tech. 4 January. Retrieved from http://www.pv-tech.org/friday_ focus/friday_focus_china_friend_or_foe_to_europe. Accessed 5 May 2015.

Clark, D. P. (2013). Shedding light on the recent US-China solar dispute. Global Economy Journal, 13(2), 251-259.

Compadre, C. (2013). La Chine met la pression sur le vin européen. Sud Ouest.

Cuervo-Cazurra, A., \& Genc, M. (2008). Transforming disadvantages into advantages: Developing-country MNEs in the least developed countries. Journal of International Business Studies, 39(6), 957-979.

Curran, L. (2015). The impact of trade policy on global production networks: The solar panel case. Review of International Political Economy,. doi:10.1080/09692290.2015.01.1014927.

Daamen, B., Hennart, J.-F., Kim, D.-J., \& Park, J.-Y. (2007). Sources of and responses to liability of foreignness: The case of Korean companies in the Netherlands. Global Economic Review, 36(1), $17-35$.

Dahan, N. (2005). Can there be a resource-based view of politics? International Studies of Management and Organization, 35(2), 8-27.

De Gruyter, C. (2014). Samen sterk? Eigen belang lijkt sterker. NRC Handelsblad.

Denk, N., Kaufmann, L., \& Roesch, J.-F. (2012). Liabilities of Foreigness revisited: A review of contemporary studies and recommendations for future research. Journal of International Management, 18(4), 322-334.

Denzau, A. T., \& North, D. C. (1994). Shared mental models: Ideologies and institutions. Kyklos, 47(1), 3-31.

Ding, Q (2011). Debt crisis may cause more trade friction. China Daily.

Donaldson, T. (1996). Values in tension: ethics away from home". Harvard Business Review, 74(5), 48-62.

Dunford, M., Kyoung, H. L., Weidong, L., \& Yeung, G. (2013). Geographical interdependence, international trade and economic dynamics: The Chinese and German solar energy industries. European Urban and Regional Studies, 20(1), 14-36.

Eckhardt, J. (2011). Firm Lobbying and EU Trade Policymaking: Reflections on the Anti-Dumping Case against Chinese and Vietnamese Shoes (2005-2011). Journal of World Trade, 45(5), 965-992.

Eden, L., \& Miller, S. (2004). Distance Matters: Liability of foreignness, institutional distance and ownership strategy. In M. Hitt \& J. Cheng (Eds.), Theories of the Multinational Enterprise: Diversity, complexity and relevance (Advances in International Management, Volume 16) (pp. 187-221). New York, NY: Emerald.

Eden, L., \& Miller, S. (2009). Revisiting Liability of Foreignness: Socio-political costs facing Chinese multinationals in the United
States. In K. Sauvant (Ed.), Investing in the United States. Is the US ready for FDI from China? (pp. 122-141). Cheltenham: Edward Elgar.

EP. (2012). EU and China: unbalanced trade? European Parliament resolution of 23 May 2012 P7_TA(2012) 0218. Brussels: European Parliament.

EPIA (2012). Global market outlook for photovoltaics until 2016. Brussels: European Photovoltaic Industry Association. Retrieved from http://www.epia.org/publications/epiapublications.html.

Erixon, F. (2014). Solar panels, telecommunication equipment-and the "modernisation" of EU trade defence policy, ECIPE Bulletin No. 5/2013, Brussels: European Centre for International Political Economy.

Evans, S. (2012). Huawei and ZTE to face EU subsidies investigation. Computer Business Review. Retrieved from http://www.cbron line.com/news/tech/networks/networking/huawei-and-zte-toface-eu-subsidies-investigation-280512.

Evenett, S. (2013). China-EU solar panel trade dispute: Rhetoric versus reality. VOX. CEPR's policy portal, 5 June. Retrieved from http://www.voxeu.org/article/china-eu-solar-panel-tradedispute-rhetoric-versus-reality.

Evenett, S., \& Vermulst, E. (2005). The politicisation of EC antidumping policy: Member states, their votes and the European Commission. The World Economy, 28(5), 701-717.

Feinberg, R. M., \& Reynolds, K. (2006). The spread of antidumping regimes and the role of retaliation in filings. Southern Economic Journal, 72(4), 877-890.

Fine, G. A., \& Sandstrom, K. (1993). Ideology in action: A pragmatic approach. Sociological Theory, 11(1), 21-38.

Gallagher, K. S., \& Zhang, F. (2013). Innovation and technology transfer across global value chains: Evidence from China's PV industry. Climate and Development Knowledge Network. Retrieved from http://fletcher.tufts.edu/News-and-Media/2013/ 07/01/Innovation-and-Technology-Transfer-Across-GlobalValue-Chains.

Garmann, S. (2014). Do government ideology and fragmentation matter for reducing $\mathrm{CO} 2$ emissions? Empirical evidence from OECD countries. Ecological Economics, 105, 1-10.

Grau, T., Huo, M., \& Neuhoff, K. (2012). Survey of photovoltaic industry and policy in Germany and China. Energy Policy, 51, 20-37.

Guar, A., Kumar, V., \& Sarathy, R. (2011). Liability of foreignness and internationalization of emerging market firms. In $\mathrm{T}$. M. Devinney, T. Pedersen, \& L. Tihanyi (Eds.), Dynamics of globalization: Location-specific advantages or liabilities of foreignness? (Advances in International Management, Volume 24) (pp. 211-233). New York, NY: Emerald.

Haase, M. \& Raufflet, E. (2012). Ethical oil—on the role of ideology on business practices and the making of markets in the Canadian tar sands industry. In M. Haase \& M. Kleinaltenkamp (Eds.), Proceedings of the 37th Annual macromarketing conference 2012, sustainable development of markets and marketing systems in a globalized world (pp. 377-391).

Haley, U. C. V., \& Haley, G. T. (2013). Subsidies to Chinese industry. New York: Oxford University Press.

Haley, U. C. V., \& Schuler, D. A. (2011). Government policy and firm strategy in the solar photovoltaic industry. California Management Review, 54(1), 17-38.

Halper, S. (2010). Beijing's coalition of the willing. Foreign Policy, $180,100-102$.

Halper, S. (2011). The China threat. Foreign Policy, 185, 18-19.

Hou, X., \& Ren, R. (2006). Cooperate or antagonize: The EU's dilemma on anti-dumping and safeguard measures against China. China and World Economy, 14(6), 70-84.

Jormanainen, I., \& Koveshnikov, A. (2012). International activities of emerging market firms: A critical assessment of research in top 
international management journals. Management International Review, 52, 691-725.

Klossek, A., Linke, B. M., \& Nippa, M. (2012). Chinese enterprises in Germany: Establishment modes and strategies to mitigate the liability of foreignness. Journal of World Business, 47(1), 35-44.

Kolk, A. (2010a). Social and sustainability dimensions of regionalization and (semi)globalization. Multinational Business Review, 18(1), 51-72.

Kolk, A. (2010b). Multinationals and corporate social responsibility. Politeia, XXVI(98), 138-152.

Kolk, A. (2015). The social responsibility of international business: From ethics and the environment to CSR and sustainable development. Journal of World Business,. doi:10.1016/j.jwb. 2015.08.010

Kolk, A., \& Pinkse, J. (2008). A perspective on multinational enterprises and climate change. Learning from an 'inconvenient truth'? Journal of International Business Studies, 39(8), $1359-1378$.

Kothari, T., Kotabe, M., \& Murphy, P. (2013). Rules of the game for emerging market multinational companies from China and India. Journal of International Management, 19(3), 276-299.

Kumar, V., Mudambi, R., \& Gray, S. (2013). Internationalization, innovation and institutions: The 3 I's underpinning the competitiveness of emerging market firms. Journal of International Management, 19(3), 203-206.

Lewis, J. I. (2014). The rise of renewable energy protectionism: Emerging trade conflicts and implications for low carbon development. Global Environmental Politics, 14(4), 10-35.

Liu, Y. (2005). Anti-dumping actions and China. Journal of Financial Crime, 12(3), 272-289.

Luo, Y., \& Mezias, J. (2002). Liabilities of foreignness: Concepts, constructs and consequences. Journal of International Management, 8(3), 217-221.

Mavroidis, P. (2013). Driftin' too far from the shore-Why the test for compliance with the TBT agreement developed by the WTO Appellate Body is wrong and what should the $\mathrm{AB}$ have done instead. World Trade Review, 12(3), 509-553.

McGuire, S., Lindeque, J., \& Suder, G. (2012). Learning and lobbying: Emerging market firms and corporate political activity in Europe. European Journal of International Management, 6(3), 342-362.

Mezias, J. M. (2002). Identifying liabilities of foreignness and strategies to minimize their effects: the case of labor lawsuit judgments in the United States. Strategic Management Journal, 23(3), 229-244.

Miller, S., \& Eden, L. (2006). Local density and foreign subsidiary performance. Academy of Management Journal, 49(2), 341-355.

Moeller, M., Harvey, M., Griffith, D., \& Richey, G. (2013). The impact of country-of-origin on the acceptance of foreign subsidiaries in host countries: An examination of the 'liabilityof-foreignness'. International Business Review, 22(1), 89-99.

Nahm, J., \& Steinfeld, E. (2014). Scale-up nation: China's specialization in innovative manufacturing. World Development, 54, 288-300.

Nordström, H. (2011). The political economy of EU anti-dumping policy: Decoding member states votes. Geneva: WTO. Retrieved from www.wto.org/english/res_e/reser_e/gtdw_e/wkshop11_e/ nordstrom_e.pdf.

Oliver, C. (2014). Brussels drops anti-subsidies case against Chinese groups. Financial Times.

Petersen, B., \& Pedersen, T. (2002). Coping with liability of foreignness: Different learning engagements of entrant firms. Journal of International Management, 8(3), 339-350.

Pinkse, J., Bohnsack, R., \& Kolk, A. (2014). The role of public and private protection in disruptive innovation: The automotive industry and the emergence of low-emission vehicles. Journal of Product Innovation Management, 31(1), 43-60.
Pinkse, J., \& Kolk, A. (2012). Multinational enterprises and climate change: Exploring institutional failures and embeddedness. Journal of International Business Studies, 43(3), 332-341.

Prognos (2013). The impact of anti-dumping and/or countervailing measures on imports of solar modules, cells and wafers from China on EU employment and value added. Basle, Switzerland. Retrieved from http://AFASE.org/en/action/prognos-pv-jobsstudy.

ProSun (2012a). Injury indicators in the AD solar complaints. Memo. Retrieved from www.prosun.org.

ProSun (2012b). European solar manufacturers welcome European Parliament debate on Chinese dumping. Press Release, 23 November.

ProSun (2013a). Briefing Paper: Chinese dumping is seriously injuring the European solar industry and European suppliers, and endangers future solar installations in Europe. Retrieved from http://www.prosun.org/en/media/media-downloads.html.

Prosun (2013b). Alarming situation for solar companies. Memo. Retrieved from http://www.prosun.org/en/media/media-down loads.html.

ProSun (2013c). AFASE must stop talking nonsense. Chinese lobby group deliberately destabilizes European solar sector and politicians. Brussels, 17 July.

ProSun (2013d). European solar industry sues against compromise in trade dispute with China. Brussels, 27 July. Retrieved from http://www.prosun.org/en/media/media-downloads.html.

ProSun (2013e). Anti-dumping measures secure employment in Europe, dumping destroys jobs. Press Release, 9 May. Retrieved from http://www.prosun.org/en/media/media-downloads.html.

ProSun (2013f). Anti-dumping measures promote EU solar jobs and growth. New PwC study on the impact of duties on EU solar market. Press Release, 10 May.

ProSun (2014a). Massive violation of EU trade deal by Chinese solar manufacturers. Brussels, 5 June. Retrieved from http://www. prosun.org/en.html.

ProSun (2014b). European Commission surrenders EU solar industry to China, while US imposes $50 \%$ tariffs. Brussels, 30 July. Retrieved from http://www.prosun.org/en.html.

ProSun (2015). Illegal Solar Trade: New action against Chinese dumping. 29th April. Retrieved from http://www.prosun.org/en.html.

Prusa, T. \& Skeath, S. (2001). The economic and strategic motives for anti-dumping filings. NBER Working Paper No. 8424.

PWC (2013). Review of Prognos' study published in the course of the EU antidumping and anti-subsidy investigations on imports of photovoltaic products from China. Published by Prosun. Retrieved from < http://www.prosun.org/en/media/media-down loads.html.

Quitzow, R. (2015). Dynamics of a policy-driven market: The coevolution of technological innovation systems for solar photovoltaics in China and Germany. Environmental Innovation and Societal Transitions,. doi:10.1016/j.eist.2014.12.002.

Ramachandran, J., \& Pant, A. (2010). The liabilities of origin: An emerging economy perspective on the costs of doing business abroad. In T. M. Devinney, T. Pedersen, \& L. Tihanyi (Eds.), The past, present and future of international business and management (Advances in International Management, Volume 23) (pp. 231-265). New York, NY: Emerald.

Rubini, L (2011). The subsidization of renewable energy in the WTO: Issues and perspectives. Swiss National Centre for Competence in Research (NCCR), Working Paper no 2011/32. Retrieved from http://www.nccr-trade.org/publication/subsidization-ofrenewable-energy-in-the-wto/.

Scott, J., \& Wilkinson, R. (2013). China Threat? Evidence from the WTO. Journal of World Trade, 47(4), 761-782.

Sethi, D., \& Judge, W. (2009). Reappraising liabilities of foreignness within an integrated perspective of the costs and benefits of 
doing business abroad. International Business Review, 18(4), 404-416.

SETI (2014). Q\&A on the application of EU duties and undertakings on solar cells and modules from China. 31 October.

SETI (2015). Status of the EU anti-dumping and anti-subsidy proceedings. Ongoing developments. 5 May 2015. Retrieved from http://seti-alliance.org/sites/default/files/status_of_the_eu_ anti-dumping_and_anti-subsidy_proceedings.pdf.

Shortgen, F. (2009). A contextual view of Chinese enterprise internationalization. In I. Alon, J. Chang, M. Fetscherin, C. Lattemann, \& J. McIntyre (Eds.), China rules (pp. 15-45). Basingstoke: Palgrave Macmillan.

SolarWorld (2012). SolarWorld welcomes anti-dumping investigation by European Commission. Press release, 6 September 2012. Retrieved from http://www.solarworld.de/en/press/press-releases/ corporate-news-ad-hoc/single-ansicht/article/solarworld-welcomesanti-dumping-investigation-by-european-commission-1/.

Stevens, C. E., \& Shenkar, O. (2012). The liability of home: Institutional friction and firm disadvantage abroad. In L. Tihanyi, T. M. Devinney, \& T. Pedersen (Eds.), Institutional theory in international business and management (Advances in International Management, Volume 25) (pp. 127-148). New York, NY: Emerald.

Trina Solar (2012). Annual Report 2011. Retrieved from http://www. trinasolar.com/eu/about-us/Management-Team.html.

Trina Solar (2013). Trina Solar Statement on preliminary determination of anti-dumping duty in EU. 5 June. Retrieved from http:// www.trinasolar.com/eu/about-us/newinfo_276.html.

Tully, S. (Ed.). (2005). International documents on corporate responsibility. Cheltenham, UK and Northampton, MA: Edward Elgar.

Van de Graaf, T. (2013). Contradictions in EU-China clean energy relations. Paper prepared for the conference: The EU and Emerging powers. European Parliament. Brussels. Retrieved from http://www.iee-fusl.eu/1068.html.
Verbeke, A. (2009). International business strategy. Cambridge: Cambridge University Press.

Wines, W. A., \& Hamilton, J. B. (2009). On changing organizational cultures by injecting new ideologies: The power of stories. Journal of Business Ethics, 89, 433-447.

WWF (2013). Position paper on the proposed punitive tariffs on Chinese solar panels. WWF and Nature and Environment, 30 May. Retrieved from http://awsassets.panda.org/downloads/ngo positionpaper_solarpvchina_final.pdf. Accessed on 3 September 2013.

Yingli (2015). Annual Report Pursuant to Section 13 or 15(d) of the Securities Exchange Act of 1934. For the fiscal year ended December 31, 2014. Retrieved from http://ir.yinglisolar.com/ phoenix.zhtml?c=213018\&p=irol-reportsannual.

Yu, C. (2013). The dispute between China and the EU over solar panels illustrates the misunderstandings that have plagued EUChina relations. LSE IDEAS, part of the LSE EUROPP series on the Dahrendorf Symposium, 11 November, London School of Economics and Political Science. Retrieved from http://blogs.lse. ac.uk/ideas/2013/11/the-dispute-between-china-and-the-eu-oversolar-panels-illustrates-the-misunderstandings-that-have-plaguedeu-china-relations/.

Zaheer, S. (1995). Overcoming the liability of foreignness. Academy of Management Journal, 38(2), 341-363.

Zaheer, S. (2002). The liability of foreignness, redux: A commentary. Journal of International Management, 8(3), 351-358.

Zaheer, S., \& Mosakowski, E. (1997). The dynamics of the liability of foreignness: A global study of survival in financial services. Strategic Management Journal, 18(6), 439-463.

Zhang, S., Andrews-Speed, P., Zhao, X., \& He, Y. (2013). Interactions between renewable energy policy and renewable energy industrial policy: A critical analysis of China's policy approach to renewable energies. Energy Policy, 62, 342-353. 